\title{
Natural transovarial transmission of dengue virus 4 in Aedes aegypti from Cuiabá, State of Mato Grosso, Brazil
}

\author{
Lucinéia Claudia de Toni Aquino da Cruz ${ }^{[1]}$, Otacília Pereira Serra ${ }^{[2]}$, \\ Fábio Alexandre Leal-Santos ${ }^{[3]}$, Ana Lucia Maria Ribeiro ${ }^{[4]}$, \\ Renata Dezengrini Slhessarenko ${ }^{[2]}$ and Marina Atanaka dos Santos ${ }^{[1]}$
}

[1]. Instituto de Saúde Coletiva, Universidade Federal de Mato Grosso, Cuiabá, MT. [2]. Departamento de Ciências Básicas da Saúde, Faculdade de Medicina, Laboratório de Virologia, Universidade Federal de Mato Grosso, Cuiabá, MT. [3]. Departamento GPA da Saúde, Centro Universitário de Várzea Grande, Várzea Grande, MT. [4]. Departamento de Ciências Básicas da Saúde, Faculdade de Medicina, Laboratório de Entomologia, Universidade Federal de Mato Grosso, Cuiabá, MT.

\begin{abstract}
Introduction: Dengue is the most prevalent arboviral disease in tropical areas. In Mato Grosso, outbreaks are reported every year, but studies on dengue in this state are scarce. Methods: Natural transovarial infection of Aedes aegypti by a flavivirus was investigated in the Jardim Industriário neighborhood of Cuiabá, Mato Grosso. Eggs were collected with ovitraps during the dry, intermediate, and rainy seasons of 2012. After the eggs hatched and the larvae developed to adulthood, mosquitoes $(\mathrm{n}=758)$ were identified and allocated to pools of 1-10 specimens according to the collection location, sex, and climatic period. After RNA extraction, multiplex semi-nested RT-PCR was performed to detect the four dengue virus (DENV) serotypes, yellow fever virus, West Nile virus and Saint Louis encephalitis virus. Results: DENV-4 was the only flavivirus detected, and it was found in 8/50 pools (16.0\%). Three of the positive pools contained females, and five contained males. Their nucleotide sequences presented $96-100 \%$ similarity with DENV-4 genotype II strains from Manaus, Amazonas. The minimum infection rate was 10.5 per 1000 specimens, and the maximum likelihood estimator of the infection rate was 11.6 (95\% confidence interval: 4.8; 23.3). Conclusions: This study provides the first evidence of natural transovarial infection by DENV-4 in Ae. Aegypti in Mato Grosso, suggesting that this type of infection might serve as a mechanism of virus maintenance during interepidemic periods in Cuiabá, a city where dengue epidemics are reported every year. These results emphasize the need for efficient vector population control measures to prevent arbovirus outbreaks in the state.
\end{abstract}

Keywords: Aedes aegypti. Flavivirus. Vertical transmission. Entomological surveillance.

\section{INTRODUCTION}

Dengue poses a significant public health problem in tropical areas worldwide and has been one of the most important reemerging epidemics in recent years ${ }^{(1)(2)}$. Dengue reemergence is in part attributed to the failure of vector control measures and uncontrolled urbanization combined with certain virus characteristics $^{(1)}$. Dengue virus (DENV) is a member of the Flaviviridae family and Flavivirus genus. Four antigenically distinct serotypes (DENV-1, 2, 3, and 4) have been described; several intra-serotype genotypes are present, and lineages exhibit up to $6 \%$ divergence in the E/NS1 genome sequences ${ }^{(3)(4)}$. Despite the existence of sylvatic cycles of DENV transmission in Africa and Asia involving primates and sylvatic Aedes species, the viral transmission is essentially urban in the Americas. Here,

\footnotetext{
Address to: Ms. Lucinéia Claudia de Toni Aquino da Cruz. ICS/UFMT. Av. Fernando Correa da Costa, 2367, CCBS-III, Bairro Boa Esperança, 78060-900 Cuiabá, MT, Brasil.

Phone: 5565 9982-7228

e-mail: lucineiadetoni@gmail.com

Received 4 November 2014

Accepted 20 January 2015
}

the environmental conditions associated with the presence of infected vectors and susceptible hosts promote the transmission cycle of the virus ${ }^{(5)}$.

Brazil is responsible for the majority of annual dengue notifications to the World Health Organization from the Americas $^{(6)}$. The country has ideal ecological conditions for arbovirus maintenance and dissemination due to the existence of densely populated urban centers infested with the highly anthropophilic vector Aedes aegypti ${ }^{(7)}$. All four DENV serotypes have been described in Brazil, and the frequencies of these serotypes within the population vary by region.

The reintroduction of DENV-4 into the country was first observed in 2008 in Manaus, Amazonas (AM), followed by reports in 2010 in Boa Vista, Roraima (RR), with subsequent dissemination throughout the country ${ }^{(8)(9)}$. This serotype spread rapidly through the population, most likely due to a lack of immunity; it had not been observed since 1982 in the country ${ }^{(10)}$. In 2012, more than 120 thousand cases of dengue were reported in Brazil, with 44,814 in the state of Mato Grosso (MT) ${ }^{(11)}$. Most of the cases occurring in 2012 were reported in Cuiabá, the state capital (10,742 cases, two fatal). All four DENV serotypes were detected in the city throughout this year, but DENV-4 was responsible for the vast majority of the cases ${ }^{(12)}$. 
Aedes Aegypti is also the urban vector of yellow fever virus (YFV). Sporadic human cases in Brazil have been attributed to the sylvatic cycle of transmission since 1942, when the urban cycle was eradicated from the country by massive vaccination of the population. Mato Grosso is considered a risky area for outbreaks, and vaccination is recommended ${ }^{(13)(14)}$.

The Saint Louis encephalitis virus (SLEV) was described during a dengue outbreak in 20 patients from São José do Rio Preto. Additionally, one human case was reported in Ribeirão Preto, and the virus was detected in three patients from Mato Grosso ${ }^{(12)(15)(16)}$. Additional evidence of SLEV circulation in Brazil among humans, equines, mosquitoes, birds, and vectors in the Amazon region, the State of São Paulo, and the southern Pantanal has also been reported ${ }^{(17)(18)(19)}$.

Serological evidence of West Nile virus (WNV) circulation has been described in the Brazilian Pantanal ${ }^{(20)(21)}$. Both viruses, SLEV and WNV, have also been reported in Aedes mosquitoes elsewhere ${ }^{(22)(23)}$.

Vertical transmission is a possible mechanism of viral maintenance in nature for various Flavivirus species $^{(24)(25)}$. To explore this phenomenon, several studies have been conducted recently in several regions ${ }^{(26)(27)(28)}$. Because the country spans much of the continent, dengue epidemiology may vary considerably between regions. This study aimed to estimate the rates of natural transovarial infection by Flavivirus species in an area of Cuiabá, MT that has a high incidence of acute febrile illness suspected to be caused by dengue infection.

\section{METHODS}

\section{Sampling}

A prospective study was conducted in the Jardim Industriário II neighborhood of Cuiabá, MT. This area is located in the south of the city $\left(15^{\circ} 39^{\prime} 10^{\prime \prime} \mathrm{S}\right.$ and $\left.55^{\circ} 58^{\prime} 20^{\prime \prime} \mathrm{W}, 211 \mathrm{~m}\right)$, with an estimated 5,300 inhabitants ${ }^{(29)}$. Ovitraps were placed in 10 peridomiciliary premises (Figure 1 and 2). These traps were constructed and installed according to the methods of Fay and Aliason $^{(30)}$. Three captures were conducted during each climatic period of 2012 (i.e., the rainy (24/01 to 08/02), intermediate (07/05 to $22 / 05)$, and dry (04/07 to $08 / 08)$ seasons) following a stratified sampling protocol to obtain a representative sample from the area; 90 pallets were used in total. The eggs were counted, and after emergence and development to adulthood (i.e., approximately seven days), the specific size and sex of the living specimens in a dormant state (i.e., at $-20^{\circ} \mathrm{C}$ for four minutes) were identified using a dichotomous $\mathrm{key}^{(31)}$. The specimens were then allocated to pools of 1-10 mosquitoes according to the collection location and stored at $-80^{\circ} \mathrm{C}$.

\section{RNA extraction and multiplex semi-nested reverse transcriptase (RT)-PCR for flaviviruses}

Mosquito pools were minced in $0.8 \mathrm{~mL}$ of saline solution (RNAse-free phosphate buffered saline, $\mathrm{pH}$ 7.0) and centrifuged for 4 min at $2,500 \times g$ and $4^{\circ} \mathrm{C}$. Total RNA extraction was

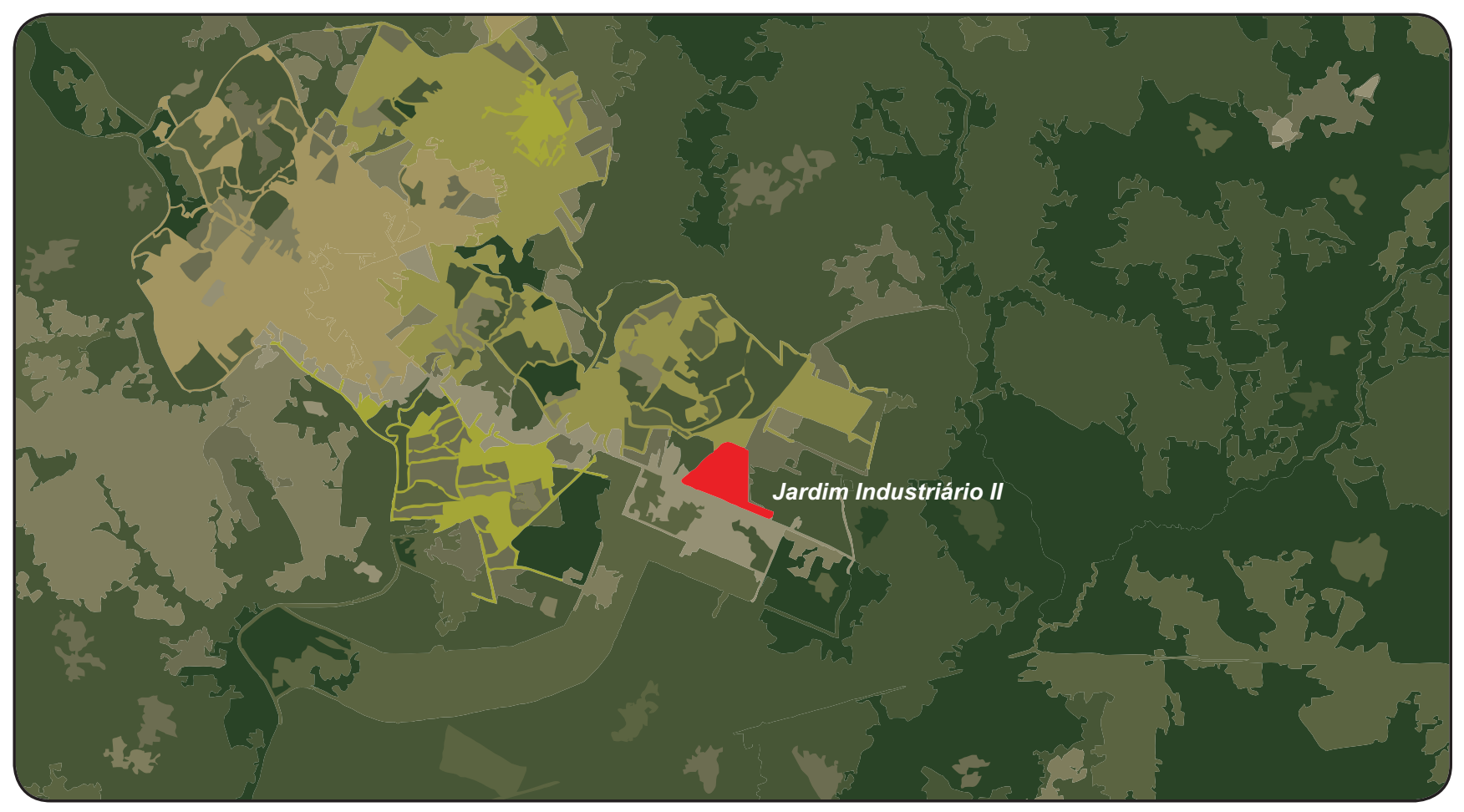

FIGURE 1 - Map of the study area, Jardim Industriário II, in Cuiabá, State of Mato Grosso. 


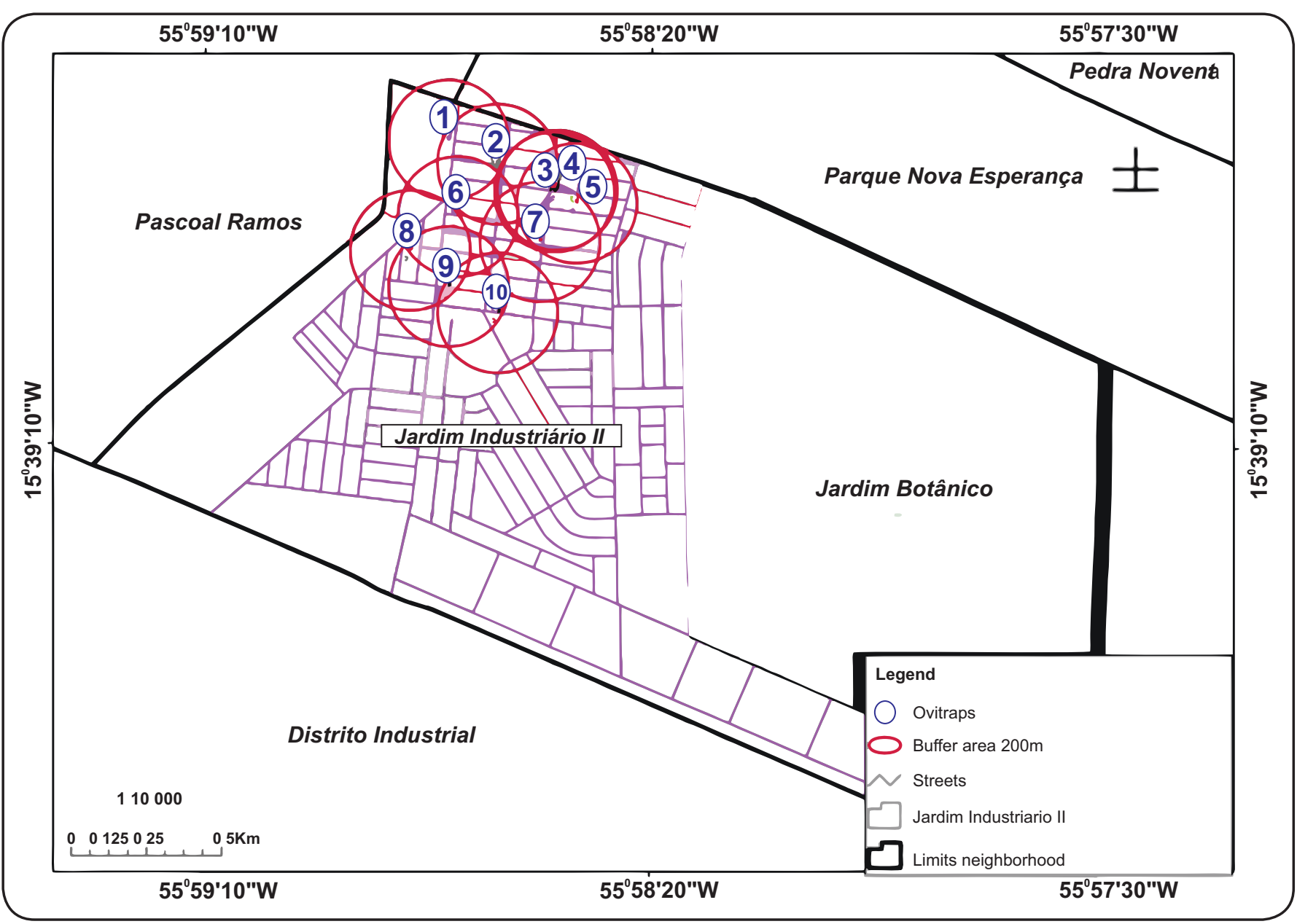

FIGURE 2 - Map showing the locations of the geo-tagged ovitraps installed in Jardim Industriário II, within the city of Cuiabá, State of Mato Grosso in 2012 to collect eggs from mosquitoes of the genus Aedes during the wet, intermediate, and dry seasons.

performed using TRIzol (Invitrogen) in $0.4 \mathrm{~mL}$ of supernatant according to the manufacturer's instructions. The total RNA was reverse transcribed using $100 \mathrm{U}$ of reverse transcriptase (Superscript III, Invitrogen), a generic flavivirus primer, $10 \mu \mathrm{L}$ of RNA, and $20 \mathrm{U}$ of RNAse inhibitor (RNAse OUT, Invitrogen). The mixture was incubated for $50 \mathrm{~min}$ at $50^{\circ} \mathrm{C}$ and $15 \mathrm{~min}$ at $70^{\circ} \mathrm{C}^{(32)(33)(34)}$. The cDNA $(8 \mu \mathrm{L})$ was subjected to multiplex semi-nested PCR to detect the DENV serotypes, YFV, WNV, and SLEV ${ }^{(34)}$. Complementary DNA from positive controls was included in the reactions (i.e., DENV-4 strain Boa Vista, SLEV BeH 355964, and YFV 17DD), and a negative control without DNA template (Table 1). An aliquot of $15 \mu \mathrm{L}$ of amplification products was submitted to electrophoresis on a 1.5\% agarose gel (Figure 3).

RNA from the positive pools was subjected independently to single multiplex semi-nested RT-PCR with the primers for DENV-4 used in the multiplex reaction. The products were sequenced (3500 Genetic Analyzer, Applied Biosystems) to confirm the species identification. Sequences were aligned and analyzed with the software Molecular Evolutionary Genetics Analysis (MEGA) 5.2 and the nucleotide Basic Local Alignment
Tool (BLASTn) (NCBI) and then deposited in GenBank (NCBI) under the accession numbers KM191331, KM191332, and KM191333.

\section{Data analysis}

Point estimates and confidence intervals for the prevalence of infection in mosquitoes were calculated with the software Pool Screen, which was kindly provided by the Department of Biostatistics, School of Public Health, University of Alabama (Birmingham, AL). The minimum infection rate (MIR) was calculated as the number of positive pools divided by the number of specimens tested and multiplied by $1,000^{(35)(36)}$.

\section{RESULTS}

During the study period, 2,628 eggs were collected from which $758 \mathrm{Ae}$. aegypti adults emerged: 351 males and 407 females. These adults were allocated to 50 pools ( 24 pools of females and 26 pools of males) of 1-10 specimens each, with the aim of identifying the frequency of transovarial natural infection by flaviviruses. Among these pools, eight were positive 


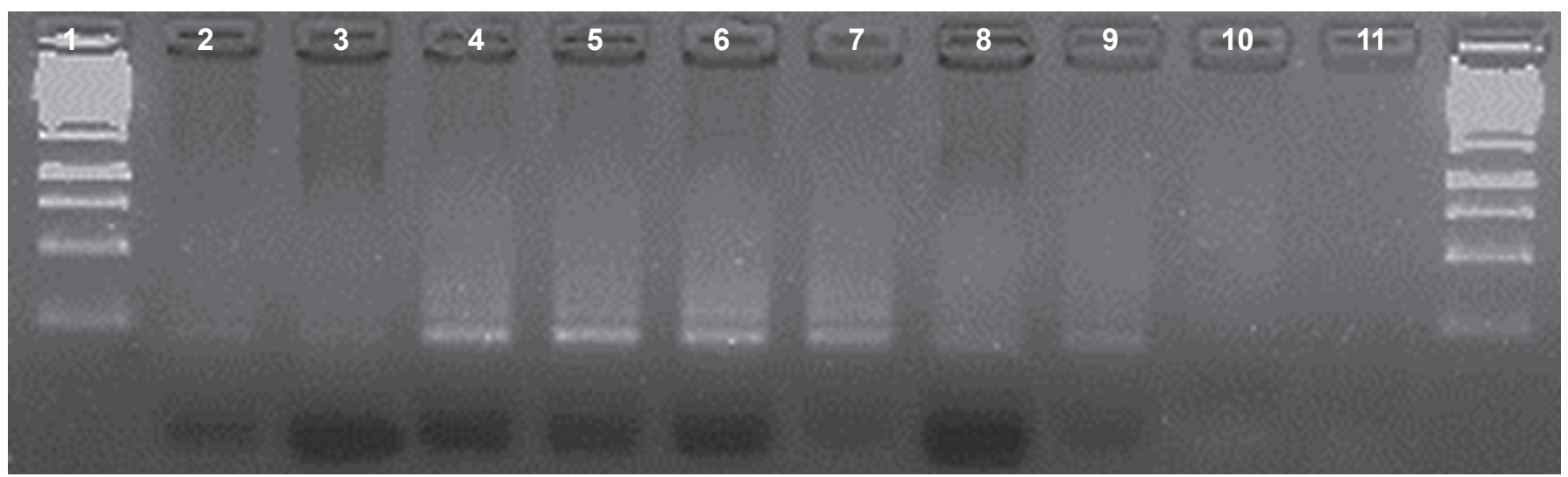

FIGURE 3 - Products of multiplex semi-nested RT-PCR obtained from pools of 1-10 Aedes aegypti mosquitoes infected with dengue 4 (DENV-4) virus, hatched in the ovitraps installed in the Jardim Industriário II neighborhood of Cuiabá, State of Mato Grosso in 2012. 1: molecular weight marker; 2-9: pools positive for DENV-4; 10: negative control; 11: template molecular weight marker.

TABLE 1 - Primers used in semi-nested multiplex reverse transcription-PCR for the non-structural protein NS5 of dengue virus serotypes (DENV-1, 2, 3, and 4), yellow fever virus (YFV), West Nile virus (WNV), and Saint Louis encephalitis virus (SLEV) ${ }^{(34)}$.

\begin{tabular}{|c|c|c|c|c|}
\hline \multicolumn{3}{|l|}{ Target $^{\mathrm{a}}$} & \multirow{2}{*}{$\begin{array}{c}\begin{array}{c}\text { Position } \\
\text { in genome }\end{array} \\
8270-8297\end{array}$} & \multirow{2}{*}{$\begin{array}{c}\begin{array}{c}\text { Amplicon } \\
(\mathrm{bp})^{\mathrm{a}}\end{array} \\
988\end{array}$} \\
\hline Genus & FG1(+) & TCAAGGAACTCCACACATGAGATGTACT & & \\
\hline Flavivirus & FG2(-) & GTGTCCCATCCTGCTGTGTCATCAGCATACA & $9228-9258$ & \\
\hline \multicolumn{5}{|c|}{ Species-specific primers: multiplex semi-nested RT-PCR ${ }^{b}$} \\
\hline DENV-2 & nDEN2(-) & GAACCAGTTTGTTTDRTTTCATAGCTGCC & $8488-8516$ & 316 \\
\hline DENV-3 & nDEN3(-) & CCCATTGGTTCTCCTCTGTG & $8800-8819$ & 628 \\
\hline DENV-4 & nDEN4(-) & GCAATCGCTGAAGCCTTCTCCC & $8394-8415$ & 222 \\
\hline YFV & nYF(-) & TCAGAAGACCAAGAGGTCATGT & $8502-8523$ & 253 \\
\hline
\end{tabular}

abp: base pairs; ${ }^{\mathbf{b}_{\mathrm{U}}} \mathrm{Used}$ in reaction with the initiator FG1 for flaviviruses.

TABLE 2 - Specimens of Aedes aegypti larvae hatched from eggs collected in ovitraps; pools were tested by multiplex semi-nested RT-PCR for dengue virus 4. Minimum rate of infection, maximum likelihood estimator and confidence intervals (95\% CI) for the Jardim Industriário II, City of Cuiabá, State of Mato Grosso in 2012.

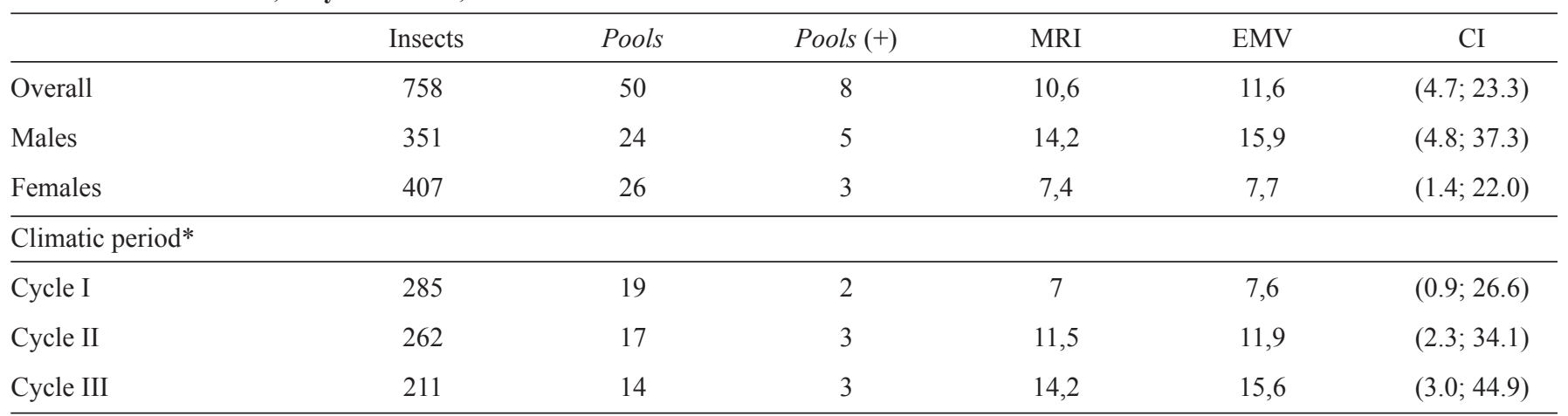

MRI: minimum infection rate, calculated from the number of positive pools divided by the total number of insects tested $\times 1,000$; EMV: maximum likelihood estimator; CI: confidence interval; *Cycle I: rainy; Cycle II: intermediate; Cycle III: dry. 
for DENV-4: two were obtained in the rainy season, three in the intermediate season, and three in the dry season. Three of the positive pools contained females and five contained males (Table 2). No flavivirus other than DENV-4 was detected. The MIR was 10.5\% (8/758, 95\% confidence interval: 4.7; 23.3). The MIR was $14.2 \%$ among males, $7.4 \%$ among females, $14.2 \%$ in the dry season, $11 \%$ in the intermediate period, and $7 \%$ in the rainy season. Three PCR products obtained from DENV-4 positive pools were submitted for nucleotide sequencing; they presented between 96 and 100\% similarity with the strain H780563 (GenBank accession number JQ513343), which belongs to genotype II of DENV-4 and was previously isolated from a human sample in Manaus, $\mathrm{AM}^{(37)}$.

\section{DISCUSSION}

Dengue is endemic in MT. During 2012, the introduction of the DENV-4 serotype was detected in the state and was accompanied by a massive outbreak in the metropolitan area of the capital, Cuiabá. Annually, an unexplained higher incidence of the disease is observed in certain areas of the city, such as the Jardim Industriário neighborhood ${ }^{(38)}$. This study was conducted to investigate the possible reasons for this higher incidence and consequent higher prevalence of the disease in these areas. Possible causes of the high prevalence of dengue in these neighborhoods primarily include the presence of a critical degree of Ae. aegypti proliferation, the presence of many eggs and the frequency of transovarial DENV-4 infections among mosquitoes. In 2012, the average frequency of Ae. Aegypti estimated using LIRAa (Quick Survey Index Aedes aegypti) in the neighborhoods comprising the Jardim Industriário region was $7.9 \%$. This rate is considered high, as the rate recommended by the Ministry of Health is $1 \%{ }^{(39)}$.

In this study, the DENV-4 MIR for Ae. aegypti naturally infected via the transovarial route was $10.5 \%$ (8/758). Similar data were obtained in a study conducted on adult females obtained from the pupal and larval stages of Aedes in Fortaleza, Ceará, an area with an elevated incidence of dengue. The MIR was 0.5 and 9.4 for Ae. Aegypti and Ae. albopictus, respectively. During the study period, DENV-2 and DENV-3 were the predominant serotypes in the regions where the immature stages of the vector were sampled ${ }^{(27)}$.

The nucleotide sequence analysis revealed a high degree of similarity with the DENV-4 genotype II from Manaus, AM. This isolate was described in a spatiotemporal study, which provided evidence of at least three introductions of DENV-4 genotype II to Brazil, two from Venezuela to Roraima and one from Colombia to Amazonas, in 2008-2010. After its introduction, DENV-4 exhibited a rapid geographic spread, most likely due to the lack of immunity in the population; this serotype had not been observed in Brazil since 1982(37).

Transovarial transmission of DENV may be passed through generations of Ae. aegypti in the absence of infection of the vector by blood feeding, supporting the maintenance of the virus in nature in the absence of susceptible hosts or during adverse environmental conditions ${ }^{(23)(40)}$.
In MT, intense efforts are made to achieve vectorial control during the rainy season (December to April). Epidemiological surveillance is conducted throughout the year to monitor and investigate high-priority areas with elevated Ae. aegypti infestation indexes ${ }^{(38)}$. Positivity for DENV-4 was found during each of the three climatic periods (Table 2), indicating that transovarial transmission is not restricted to the vectorial population peaks observed during the rainy season. These findings indicate that vectors are being born already infected and able to transmit the virus at the beginning of epidemics. This ability might serve as a mechanism of virus maintenance between interepidemic periods, thereby favoring DENV transmission to susceptible hosts and subsequent dengue outbreaks in the studied neighborhood.

During one year of evaluation, elevated levels of natural transovarial infection (MIR $=24.4 \%$ ) were reported in Thailand four months before a large dengue outbreak ${ }^{(41)}$. The authors of this study detected all four DENV serotypes, but DENV-4 predominated, followed by DENV-3, DENV-1, and DENV2. Another study with Ae. Aegypti and Ae. Albopictus in the same location that examined adults obtained from immature stages was not able to find any positivity for $\mathrm{DENV}^{(42)}$. Studies conducted in Bolivia, Taiwan, Southeast Asia, Singapore and French Guiana have reported relatively low rates of natural transovarial infection, with MIR indexes ranging from $0.13 \%$ to $0.97 \%$ for various DENV serotypes ${ }^{(26)(43)(44)(45)(46)}$.

In Roraima, Aedes aegypti larvae collected in an urban area tested negative for $\mathrm{DENV}^{(47)}$. The authors of this study concluded that natural transovarial transmission might not be an important mechanism for DENV maintenance in the city, and consequently, the presence of susceptible hosts might be frequent in endemic areas. The life cycle of the mosquito may also indicate that infection rates are diluted between generations. However, these conclusions are not applicable to Cuiabá.

In this study, five pools of Ae. Aegypti containing males and three containing females were positive for DENV-4. In addition to the epidemiological relevance of DENV detection in Ae. aegypti females, which are implicated in the transmission of the virus by their hematophagic and essential anthropophilic habits, DENV infections in male mosquitoes are also relevant; they are considered to be a more precise indicator of natural transovarial transmission because they feed only on plant nectar ${ }^{(48)}$. Moreover, infected males are able to transmit the virus to females during reproduction, resulting in transmission to their $\operatorname{eggs}^{(49)}$.

None of the pools of Ae. Aegypti was positive for YFV in this study. This result was expected because urban transmission of this virus has not been reported in Brazil since 1942. One study conducted in Senegal reported transovarial infection with a MIR of $0.97 \%$ in adults emerging from the eggs of females experimentally infected through the oral route ${ }^{(50)}$.

Additionally in this study, we did not find any Ae. aegypti pools that were positive for WNV or SLEV. Certain Culicidae species are able to transmit WNV vertically, carrying the virus in their eggs when climatic conditions are unfavorable to their proliferation ${ }^{(51)}$. In Brazil, serological evidence of WNV 
circulation in birds and equines has already been reported, demonstrating the importance of surveillance for this virus in host and vector species ${ }^{(17)(20)(21)}$. SLEV is transmitted vertically in several species of mosquitoes. Although this phenomenon has been most frequently described in the genus Culex, there are some reports involving Aedes species, exhibiting a MIR of $1 \%{ }^{(52)(53)}$. This pathogen was recently detected in three patients with dengue and in Culex spp. from Cuiabá, $\mathrm{MT}^{(12) .}$ However, the cycle of transmission of this virus in the city is poorly understood.

Some studies have demonstrated that the dynamics of flavivirus transmission is influenced by mutations, antigenic variability, ecological conditions, and host factors that affect the susceptibility to infection ${ }^{(54)}$. Although most human arbovirus infections are attributed to DENV in Brazil, it is necessary to extend surveillance to other arboviruses potentially circulating in MT, especially those that have already been reported in neighboring states. Because infection with most of these viruses is clinically characterized by undifferentiated acute febrile illness and asymptomatic infections are common, differential diagnosis through molecular methods is essential to estimate the frequency of infection by various arboviruses in the population $^{(7)}$.

Moreover, the methods currently available for vector population control have failed to control Ae. aegypti despite the efforts of governmental institutions and intensification of the measures already applied. Studies to elucidate the mechanisms of DENV maintenance in nature are scarce, and the development of new vector population control strategies is necessary ${ }^{(55)}$.

The findings reported in this study demonstrate that natural transovarial infection by DENV-4 is occurring in Ae. Aegypti in Cuiabá with a relatively high MIR index, which favors the birth of mosquitoes already infected with DENV at the beginning of epidemics. This mechanism may be responsible for virus maintenance during interepidemic periods, especially in critical areas with elevated mosquito density and human disease incidence. Entomological surveillance and data on the detection of infected mosquitoes might be used to estimate DENV serotype frequency, allowing greater understanding of the epidemiological factors that influence the occurrence of the disease in the population and further supporting the development of vector population control strategies.

\section{ACKNOWLEDGMENTS}

We wish to thank professors Rosina Djunko Miyazaki (UFMT), Jorge Senatore Vargas (Ministry of Health) and Alex Pauvolid-Corrêa (Fiocruz RJ) for their contributions into the study design and critical revisions of the manuscript.

\section{CONFLICT OF INTEREST}

The authors declare that there is no conflict of interest.

\section{FINANCIAL SUPPORT}

LCATC received a Master's Scholarship from CNPq (Conselho Nacional de Desenvolvimento Científico e Tecnológico). OPS and FALS were the recipients of a CAPES (Coordenação de Pessoal de Ensino Superior) Master's scholarship.

\section{REFERENCES}

1. Guzmán MG, Kouri G, Bravo JR. La emergencia de la fiebre hemorrágica del dengue en las Américas. Reemergencia del dengue. Rev Cubana Med Trop 1999; 51:5-13.

2. Teixeira MG, Costa MCM, Barreto F BM. Dengue: vinte e cinco anos da reemergência no Brasil. Cad Saude Publica 2009; 25: S7-S18.

3. Lindenbach BD, Thiel H, Rice CM. Flaviviridae: the viruses and their replication. fields virology, 5th ed. Lippincott-Raven Publishers, Philadelphia. 2007. p. 1101-1112.

4. Allicock OM, Lemey P, Tatem AJ, Pybus OG, Bennett SN, Mueller BA, et al. Phylogeography and population dynamics of dengue viruses in the Americas. Mol Biol Evol 2012; 29:1533-1543.

5. Marzochi KBF. Dengue in Brazil - situation, transmission and control - a proposal for ecological control. Mem Inst Oswaldo Cruz 1994; 89:235-245.

6. Rodrigues-Barraquer I, Cordeiro MT, Braga C, Souza WV, Marques ET, Cummings DAT. From re-emergence to hyperendemicity: the natural history of the dengue epidemic in Brazil. Plos Negl Trop Dis 2011; 5:e935.

7. Figueiredo RMP. Arboviroses emergentes no Brasil. Rev Soc Bras Med Trop 2007; 40:224-229.

8. Figueiredo RMP, Naveca FG, Bastos SM, Melo MN, Viana SS, Mourão MP, et al. Dengue virus type 4, Manaus, Brazil. Emerg Infect Dis 2008; 14:667-669.

9. Souza RP, Rocco IM, Maeda AY, Spenassatto C, Bisordi I, Suzuki A, et al. Dengue virus type 4 phylogenetics in Brazil 2011: looking beyond the Veil. Plos Negl Trop Dis 2011; 5:e1439.

10. Osanai CH, Travassos da Rosa AP, Tang AT, Amaral RS, Passos AC, Tauil PL. Surto de dengue em Boa Vista, Roraima. Rev Inst Med Trop São Paulo 1983; 25:53-54.

11. Ministério da Saúde. Sistema de Informação de Agravos de Notificação (SINAN) [Internet]. Notificação/investigação dengue Sinan NET/Sinan Online. [Cited 2012 July 10]. Available at: http:// sinan.saude.gov.br/sinan/login/login.jsf/.

12. Heinen LB, Zuchi N, Serra OP, Cardoso BF, Santos MA, Souto FD, et al. Saint Louis encephalitis virus in Mato Grosso, West-Central Brazil. Rev Inst Med Trop Sao Paulo, in press, 2015.

13. Romano APM, Costa ZGA, Ramos DG, Andrade MA, Jayme VS, Almeida MAB, et al. Yellow fever outbreaks in unvaccinated populations, Brazil, 2008-2009. Plos Neg1 Trop Dis 2014; 8:e2740.

14. Johansson MA, Vasconcelos PF, Staples JE. The whole iceberg: estimating the incidence of yellow fever virus infection from the number of severe cases. Trans R Soc Trop Med Hyg 2014; 108:482-487.

15. Mondini A, Cardeal IL, Lázaro E, Nunes SH, Moreira CC, Rahal P, et al. Saint Louis encephalitis virus, Brazil. Emerg Infect Dis 2007; 13:176-178. 
16. Maia FG, Chávez JH, de Souza WM, Romeiro MF, de Castro-Jorge LA, da Fonseca BA, et al. Infection with Saint Louis encephalitis virus in the city of Ribeirão Preto, Brazil: report of one case. Int J Infect Dis 2014; 26:96-97.

17. Pauvolid-Corrêa A, Tavares FN, Veiga E, Burlandy FM, Murta M, Pellegrin AO, et al. Serologic evidence of the recent circulation of Saint Louis encephalitis virus and high prevalence of equine encephalitis viruses in horses in the Nhecolândia sub-region in South Pantanal, Central-West Brazil. Mem Inst Oswaldo Cruz 2010; 5:829-833.

18. Rodrigues SG, Oliva OP, Araujo FAA, MArtins LC, Chiang JO, Henriques DF, et al. Epidemiologia do vírus da encefalite Saint Louis na Amazônia brasileira e no Estado do Mato Grosso do Sul, Brasil: elevada prevalência de anticorpos em equinos, Brasil: elevada prevalência de anticorpos em equinos. Rev Pan-Amaz Saude 2010; 1:81-86.

19. Terzian AC, Mondini A, Bronzoni RV, Drumond BP, Ferro BP Cabrera EM. Detection of Saint Louis encephalitis virus in denguesuspected cases during a dengue 3 outbreak. Vector Borne Zoonotic Dis 2011; 11:291-300.

20. Ometto T, Durigon EL, Araujo J, Aprelon R, Aquiar DM, Cavalcante GT, et al. West Nile virus surveillance, Brazil, 2008-2010. Trans R Soc Trop Med Hyg 2013; 107:723-730.

21. Pauvolid-Corrêa A, Morales MA, Levis S, Tadeu L, Figueiredo M, Couto-lima D, et al. Neutralising antibodies for West Nile virus in horses from Brazilian Pantanal. Mem Inst Oswaldo Cruz 2011; 106:467-474.

22. Hubalek Z, Halouzka J. West Nile fever a reemerging mosquitoborne viral disease in Europe. Emerg Infect Dis 1999; 5:643-650.

23. Gubler DJ, Kuno G, Markoff L. Flavivirus. In: Knipe DM, Howley PM, editors. Fields Virology. Philadelphia, USA: Wolters Kluwer Health; 2007. p. 1153-1152.

24. Rosen L, Shroyer DA, Tesh RB, Freier JE, Lien JC. Transovarial transmission of dengue viruses by mosquitoes: Aedes albopictus and Aedes aegypti. Am J Trop Med Hyg 1983; 32:1108-1119.

25. Hull B, Tikasingh E, Souza M, Martinez R. Natural transovarial transmission of dengue 4 virus in Aedes aegypti in Trinidad. Am J Trop Med Hyg 1984; 33:1248-1250.

26. Le Goff G, Revollo J, Guerra M, Cruz M, Barja Simon Z, Roca Y, et al. Natural vertical transmission of dengue viruses by Aedes aegypti in Bolivia. Parasite 2011; 18:277-280.

27. Martins VE, Alencar CH, Kamimura MT, Araujo FMC, De Simone SG, Dutra RF, et al. Occurrence of natural vertical transmission of dengue-2 and dengue-3 viruses in Aedes aegypti and Aedes albopictus in Fortaleza, Ceara. PLoS One 2012; 7:1-18.

28. Espinosa M, Giamperetti S, Abril M, Seijo A. Vertical transmission of dengue virus in Aedes aegypti collected in Puerto Iguazú, Misiones, Argentina. Rev Inst Med Trop São Paulo 2014; 56:165167.

29. Instituto Brasileiro de Geografia e Estatística (IBGE). Censo 2000. Instituto de Pesquisa e Desenvolvimento Urbano, Diretoria de Pesquisa e Informação - IPDU/DPI, com base no Censo demográfico 2000, IBGE; 2000.

30. Fay RW, Eliason DA. A preferred oviposition site as a surveillance method for Aedes aegypti. Mosq News 1966; 26:531-535.

31. Forattini OP. Identificação de Aedes (stegomyia) Albopictus (skuse) no Brasil. Rev Saude Publica 1986; 20:244-245.

32. Fulop L, Barrett D, Phillpotts R, Martin K, Leslie D, Titball RW. Rapid identification of flaviviruses based on conserved NS5 gene sequences. J Virol Methods 1993; 44:179-188.
33. Pfeffer M, Proebster B, Kinney RM. Genus-specific detection of alphaviruses by a semi-nested reverse transcription-polymerase chain reaction. Am J Trop Med Hyg 1997; 57:709-718.

34. Bronzoni RVM, Baleotti FG, Nogueira RMR, Nunes MFL. Duplex reverse transcription-PCR followed by nested PCR assays for detection and identification of Brazilian alphaviruses and flaviviruses. J Clin Microbiol 2005; 43:696-702.

35. Chow VT, Chan YC, Yong R, Lee KM, Lim LK, Chung YK, et al. Monitoring of dengue viruses in field-caught Aedes aegypti and Aedes albopictus mosquitoes by a type-specific polymerase chain reaction and cycle sequencing. Am J Trop Med Hyg 1998; 58:578-586.

36. Rohani A, Potiwat R, Zamree I, Lee HL. Refractoriness of Aedes aegypti (Linnaeus) to dual infection with dengue and chikungunya virus. Southeast Asian J Trop Med Public Health 2009; 40:443-448.

37. Nunes MRT, Faria NR, Vasconcelos HB, Medeiros DBA, Lima CPS, Carvalho VL, et al. Phylogeography of dengue virus serotype 4, Brazil, 2010-2011. Emerg Infect Dis 2012; 18:1858-1854.

38. Secretaria Municipal de Saúde de Cuiabá. Diretoria de Vigilância, Saúde e Ambiente. Núcleo de estudos epidemiológicos. Coordenação de Vigilância de Zoonoses. Informações estratégicas de vigilância em saúde. Informe Dengue; 2014.

39. Secretaria Municipal de Saúde de Cuiabá. Diretoria de Vigilância a Saúde e Ambiente. Núcleo de Estudos Epidemiológicos. Informações de Vigilância em Saúde. Boletins da Dengue. LIRA; 2012.

40. Joshi V, Mourya DT, Sharma RC. Persistence of dengue-3 virus through transovarial transmission passage in successive generations of Aedes aegypti mosquitoes. Am J Trop Med Hyg 2002; 67:158-161.

41. Thongrungkiat S, Maneekan P, Wasinpiyamongkol L, Prummongkol S. Prospective field study of transovarial dengue-virus transmission by two different forms of Aedes aegypti in an urban area of Bangkok, Thailand. J Vector Ecol 2011; 36:147-152.

42. Hutamai S, Suwonkerd W, Suwannchote N, Somboon P, Prapanthadara La-A. A survey of dengue viral infection in Aedes aegypti and Aedes albopictus from re- epidemic areas in the north of Thailand using nucleic acid sequence based amplification assay . Southeast Asian J Trop Med Public Heal 2007; 38:448-454.

43. Chen WJ, Tsai SM, Chen SL, Ko YC, Fang AH. A study on transovarial transmission of dengue type 1 virus in Aedes aegypti. Zhonghua Minguo wei sheng wu ji mian yi xue za zhi. Chin J Microbiol 1990; 23:259-270.

44. Khin MM, Than KA. Transovarial transmission of dengue 2 virus by Aedes aegypti in nature. Am J Trop Med Hyg 1983; 32:590-594.

45. Kow CY, Koon LL, Yin PF. Detection of dengue viruses in field caught male Aedes aegypti and Aedes albopictus (Diptera: Culicidae) in Singapore by type-specific PCR . J Med Entomol 2001; 38: 475-479.

46. Fouque F, Garinci R, Gaborit P. Epidemiological and entomological surveillance of the co-circulation of DEN-1, DEN-2 and DEN-4 viruses in French Guiana. Trop Med Int Heal 2004; 9:41-46.

47. Zeidler JD, Acosta POA, Barrêto PP. Vírus dengue em larvas de Aedes aegypti e sua dinâmica de infestação, Roraima, Brasil. Rev Saude Publica 2008; 42:986-991.

48. Thavara U, Siriyasatien P, Tawatsin A, Asavadachanukorn P, Anantapreecha S, Wongwanich R, et al. Double infection of heteroserotypes of dengue viruses in field populations od Aedes aegypti and Aedes albopictus (Diptera: Culicidae) and serological features of dengue viruses found in patients in Southern Thailand. Southeast Asian J Trop Med Public Heal 2006; 37:468-476. 
49. Rosen L. Sexual transmission of dengue viruses by Aedes albopictus. Am J Trop Med Hyg 1987; 37:398-402.

50. Diallo M, Thonnon J, Fontenille D. Vertical transmission of the yellow fever virus by Aedes aegypti (Diptera, Culicidae): dynamics of infection in F1 adult progeny of orally infected females. Am J Trop Med Hyg 2000; 62:151-156.

51. Goddard LB, Roth AE, Reisen WK, Scott TW. Vertical transmission of West Nile virus by three California Culex (Diptera: Culicidae) species. J Med Entomol 2003; 40:743-746.

52. Nayar JK. Experimental vertical transmission of Saint Louis encephalitis virus by. Am J Trop Med Hyg 1986; 35:1296-1301.
53. Pelz EG, Freier JE. Vertical transmission of St. Louis encephalitis virus to autogenously developed eggs of Aedes atropalpus mosquitoes. J Am Mosq Control Assoc 1990; 6:658-661.

54. Hayes EB, Komar N, Nasci RS, Montgomery SP, Campbell GLl. Epidemiology and transmission dynamics of West Nile Virus disease. Emerg Infect Dis 2005; 11:1167-1173.

55. Donalísio MR, Glasser CM. Vigilância entomológica e controle de vetores do dengue. Rev Bras Epidemiol 2002; 5:259-279. 